\title{
THE MASS MEDIA AND THE CHRISTIAN VALUES
}

\author{
Prof. Ph.D. Traian-Alexandru MIU, \\ Faculty of Theology and Sciences of Education, \\ Valahia University of Târgoviște, \\ ROMANIA \\ E-mail: traianalexandrumiu@gmail.com
}

"I am the way, the truth, and the life" (John 14, 6)

\section{ABSTRACT}

The present society is characterized by greed for information. The mass media, considered the "fourth power in the state", feeds the "thirst" of the mankind for sensational news, the "hunger" for novel, being enslaved to the pleasures of entertainment, getting manipulated and bringing a feeling of anxiety for the soul. With numerous means of communication available (such as: printing, audio and video recordings, internet, television, etc.), the mass media has captured the interest of the people, having all the means by which information, advertising and culture can be mass-propagated. Christian values are neglected, being replaced by the ideals of the postmodern world: fun, laziness, neglect of spiritual things, etc. Often having strategic and/or material interests, the mass media is used to reach its targets by the so-called fake news. The church has the capacity to christen the mass media efforts, so that the latter aims to build the man and his spiritual progress. The power that the mass media has today must be used for the purpose of getting closer to God and to people. Goodness, love, dignity, truth, integrity must be the fundamental values that spring from the media landscape.

Keywords: the mass media; values; fake news; manipulation; information;

\section{INTRODUCTION}

The mass media has an overwhelming influence on the contemporary society due to the impressive input of information it propagates, often acquiring the valences of an ideology that does not take into account the Christian moral values. The man's appetite for information is aroused by the mass media concern that he will always be curious. Distraught with worries, often in states of disorder and anxiety, the greedy for information man has the desire to "savor" the latest gossip.

Of course, there is also the alternative to "healthy" mass media that aims to preserve and proclaim the truth in such a way that the human being can use the advantages of such an informational approach in a beneficial way. There is a fierce battle between the mass media that has as interest the imposition of a secularized lifestyle and the mass media that aims for the man to follow the right "way" by strengthening Christian values. Whether talking about the press, radio, television, cinema or the internet, directly or indirectly, the mass media is spreading its influence throughout the human society. The era that we live in has been defined as "a consumer society", but we must differentiate between the dramatic reality of exaggerated consumption, known as consumerism, and what is really wanted, that is thrift and moderation. 


\section{THE DEFINING CHARACTERISTICS OF THE MASS MEDIA}

The term "mass media", originating from English, refers to those technologies that aim to reach a mass audience. It designates the means of communication aimed at disseminating information to as many people as possible. That is why when talking about the mass media we refer to the means by which information, advertising and culture are masspropagate, being able to influence a very large number of people. ${ }^{1}$

Tomi T. Ahonen, in his book Mobile as 7th of the Mass Media: Cellphone, Cameraphone, iPhone, Smartphone, talking about the mass media evolution since the advent of the printing until the present, lists seven main means of mass information:

1) the printing (books, newspapers, magazines, posters, etc.) - starting with the end of the $15^{\text {th }}$ century;

2) audio recordings (cylinders, vinyl discs, cassettes, CDs, DVDs, etc.) - from the end of the $19^{\text {th }}$ century;

3) the cinema - from the beginning of the $20^{\text {th }}$ century;

4) the radio - from the beginning of the $20^{\text {th }}$ century;

5) the television - from the middle of the $20^{\text {th }}$ century;

6) the Internet - from the '90s;

7) the mobile phones - from the beginning of the $21^{\text {st }}$ century. ${ }^{2}$

It is obvious that today, since it has at its disposal all the seven means listed above, the mass media enjoys omnipresence in society, exercising an overwhelming influence at social level, either directly or indirectly. The influx of information is unstoppable. Wherever you look, or whatever you listen to, it is impossible not to encounter the means by which the mass media interacts with you. Thus, interaction is inevitable!

Technology has led us to live in the so-called "information society", a "revolutionary" age in which the innovations of the $20^{\text {th }}$ century are experiencing exceptional development. Fiber optics, numerous satellites, terrestrial data transmission networks meant for today's society a true informational "boom".

\section{THE MASS MEDIA INFLUENCE ON CHRISTIAN VALUES}

Nowadays, the mass media is characterized by the major influx of breaking news, by promoting stardom, entertainment, non-values just to gain "rating", and „subscribers"4.

Filtering information has become the real problem of the society we live in. The "sift" of information is required, but for this to be done expeditiously and with discernment

\footnotetext{
${ }^{1}$ Steven Coleman, „What Is Mass Media? - Definition, Types, Influence \& Examples”, Chapter 11 / Lesson 19 , see: https://study.com/academy/lesson/what-is-mass-media-definition-types-influence-examples.html, retrieved on 18.09.2019;

2 Dave Duarte, „The 7 Mass Media and the 4th Screen”, 19, January 2009, see: https://www.daveduarte.co.za/blog/2009/1/19/the-7-mass-media-and-the-4th-screen.html, retrieved on 18.09.2019;

${ }^{3}$ Rating = term that comes from English, where it means the evaluation of something, on the basis of quality and quantity criterion, or both. Today, this term is used mainly to analyze the audience and the marketing of television and radio stations, representing the degree of receptivity of certain programs broadcast by them. General (total) rating means the ratio between the number of viewers at a given time and the potential viewers who have access to a television set (which could be viewers).

${ }^{4}$ Subscriber $=$ that comes from English, which can be translated by the terms: subscriber, signer, contractor, etc. The term is used in Romanian to designate people who subscribe to certain online media channels (such as Youtube, sites selling various products, news sites, etc.). The provider aims to both publicize and increase personal benefits, and the subscriber to benefit from what the provider offers (services, information, promotions, etc.).
} 
we must cultivate in our personal lives a strong connection with the One who is "the way, the truth and the life" (John 14, 6), that is, with Jesus Christ, the source of good thinking, good work, firm decisions and error-free life. In other words, it is necessary for the present human being to adhere with all conviction to Christian values. A moral life today means getting rid of the manipulation of the mass media, being anchored in reality, but without allowing the "fashion" of the time, the secularizing spirit, the non-values be imposed on you.

The mass media offers a wide range of content, some of which are relevant to the lives of the people who access them, others that are revealed in order to gain rating and, consequently, money, but also the so-called "fake news" and "alternative facts", which are forms of false information that have been taken over by social networks and spread ("shared") on a planetary scale, most often validated as journalistic acts (World Economic Forum $2014^{7}$.

The access of an increasing number of people to Internet services has led to the spread of fake news in Romania, too, especially in certain key moments, when the purpose is also facilitated through "fabricated" news ${ }^{8}$. "According to the results of the Eurobarometer survey, conducted by the European Commission, in February 2018, more than half of the Romanians (59\%) trust the news posted on the socializing platforms, without checking them, Romania being, from this point of view, first in Europe. The majority of respondents (79\%) claim that they can distinguish fake news, and 1 in 5 Romanians share the read information."

As stated above, one of the Christian values that anchor us in Christ is the truth, $\mathrm{He}$ Himself being the source of truth and He who loves the truth and hates the lie: "Lying lips [are] abomination to the LORD: but they that deal truly [are] his delight" (Proverbs 12, 22). Truth is the path to dignity, morality, justice and peace, while lying is causing great harm to both man and society, resulting in fear, mistrust and social decline.

Starting from the "golden rule" of Christian morality, which says: "Therefore all things whatsoever ye would that men should do to you, do ye even so to them: for this is the law and the prophets" (Matthew 7,12) or "And as ye would that men should do to you, do ye also to them likewise" (Luke 6,31), we can argue the importance of anchoring in the truth. No one likes to be lied to or manipulated by hiding the truth. Of course, there are times when the human being should not find out certain things that would bring greater harm to the soul and body, but this must be thought of very carefully.

5 „Fake news" = phrase coming from English, false news

6 "Alternative facts” = phrase coming from English. This expression was first used on January 22, 2017 by Kellyanne Conway, US President Donald Trump's adviser, during a press meeting to defend Sen Spicer, the White House spokesman, who had made a false statement about the number of people who participated in Donald Trump's investing ceremony as President of the United States of America. During an interview with Chuck Todd in which he was asked to explain why Spicer lied, Kellyanne Conway said that Spicer gave the public "alternative facts." Todd replied, "Look, alternative facts are not facts. They are fake." (Eric Bradner, „Conway: Trump White House offered alternative 'facts' on crowd size”, CNN, January 23, 2017, see https://edition.cnn.com/2017/01/22/politics/kellyanne-conway-alternative-facts/index.html, retrieved on 18.09.2019).

${ }^{7}$ Marju Himma-Kadakas, „Alternative facts and fake news entering journalistic content production cycle”, in Cosmopolitan Civil Societies Journal, Vol. 9, Nr. 2, 2017, p. 26, see: https://doi.org/10.5130/ccs.v9i2.5469, retrieved on 18.09.2019.

${ }^{8}$ Grigore Iuliana, Andrada Halgaş, „«Fabricate» pentru România. Interese ascunse în ştirile false”, 9 January 2019, see: https://intelligence.sri.ro/fabricate-pentru-romania-interese-ascunse-stirile-false/, retrieved on 18.09.2019.

${ }^{9}$ Ibidem. 
The mass media pursues certain interests when distributing incorrect information in the public space. Thus, fake news is spread for two types of stakes:

„a) strategic ones - used as part of the informational offensive of a state or an organization, in order to manipulate the population, in the sense of activating it in support of ideas or, on the contrary, producing a state of apathy, disinterest, mistrust, disappointment;

b) material ones - strictly aim at obtaining financial gains." 10

Of course, the so-called "false news" can be found in the media, the difference between these and fake news being made only at the level of intentionality: the first ones are spread out of ignorance or misinterpretations, without the purpose of manipulation, while fake news is propagated with the precise intention of manipulating public opinion. "One of the most common prototypes of fake news in the domestic level corresponds to the tabloid, sensationalist style, focused on publishing clickbait news (with shocking titles that do not support the content), which contain exaggerations and do not cite the source of information. They aim to increase the number of people who access them and, implicitly, the popularity and earnings of the source." ${ }^{\prime 11}$ It does not matter if the good name and integrity of certain people are harmed, goodwill, moral education, promotion of values are not taken into account. On the contrary, non-values are those that are promoted because they keep the audience at high levels. The promotion of entertainment is the most useful weapon with which the population is conquered. The vigil prayer has been replaced by various "shows", icons by pornographic images, tolerance by violence. We see more and more people who are isolated, developing serious forms of depression. The large flow of information leads to depersonalization and loss of self-awareness.

The statement that the press/mass media is "state power" 12 requires some clarification First of all, we must reflect on the fact that the power of the mass media resides in the force with which it propagates information among people. But we must not go beyond the fact that it is also coordinated by people. If those who have this power are attached to the Christian values and promote them, if they were educated in the spirit of authentic values, and they are concerned with their perpetuation in order to create a better human society, if they are fervent sons of the Church, then the power what was given to them will produce positive results. On the other hand, if what they pursue is the interest in acquiring material goods, then we must be careful about what they produce.

According to Law 41/1994, the press (in extenso the mass media with all its channels) "has three functions: the function of informing, training and entertaining. Various press bodies can shape their profile by shifting the focus to one or the other of the three functions, so the danger is not in this shift of accent. Each function, taken separately, contains a latent, virtual danger. In this sense, information can become misinformation (also with the help of information, apparently true), training can become manipulation (distortion of a belief), and entertainment can become a modern-erotic-erotomaniac cancan, if not worse." ${ }^{\prime 3}$ The content of news in the mass media often hides the real intent. Often the message carries with it the structural change of life concepts, of the idea of communion, of moral principles, operating in

\footnotetext{
${ }^{10}$ Ibidem.

${ }^{11}$ Ibidem.

12 Tudor Cătineanu, „Cele trei puteri ale statului şi încă una, în plus. Episodul trei: Presa”, published on 13, December, 2015, 12:52, see: https://adevarul.ro/news/politica/cele-trei-puteri-statului-inca-una-plus-episodultrei-presa-1_566d4ccd7d919ed50e2d6201/index.html, retrieved on 18.09.2019.

${ }^{13}$ Ibidem.
} 
depth on human relations. Media messages are even patterns of relationship and perception that are required and that change the traditional structures of the family. ${ }^{14}$

\section{THE MISSION OF THE CHURCH AND THE MASS MEDIA}

"In the beginning was the Word, and the Word was with God, and the Word was God. The same was in the beginning with God. All things were made by him; and without him was not any thing made that was made. (John 1, 1-3). The word is the basis of divine creation, being identified with God himself by the Holy Apostle and Evangelist John. The word is the way in which people engage in dialogue, communicate, know each other and build relationships based on love. Therefore, the foundation of interpersonal relationships is the word. It is the one that feeds people so that spiritual gaps no longer exist. The word is the bearer of truth, justice, good and beautiful.

At the same time, the word can carry with it the seeds of division, hatred, envy, manipulation, etc. With a word you can tear down a whole good arrangement, you can fill the hearts of your fellows with things that are not useful and which are destined for ruin. The change of the meaning of the word, whose purpose is that of making people grow and develop, leads to the distortion of the image of God in man. We are distracted by what we are talking about and how we are talking. Today, there is an unstoppable flow of words that we must be able to sift, select according to their importance in the act of personal growing. We need to choose those words that nourish us spiritually, which contain values and are not meaningless.

In the "world of Flight"15, as Max Picard called it, meaning the era we live in, "reading a sentence from the language of this world is like jumping from one ruin of the word to another, and there seem to be holes between these ruins. It is no longer like in the world of Faith, where the sentence begins with the subject and unfolds over the predicate and object. The entire column of the subject appears overturned. (...) Words do not follow one another voluntarily, but are put in by force; there is no coordination in the sentence, but only tears. Each word points in a different direction, but does not know which one. Anarchy dominates in the sentence and, therefore, the idea does not progress as when the sentence develops from subject to object, but it is chipped and thrown from there to there. The idea, which seeks a connection with order, and through the hierarchy of order, with God, will be isolated in the anarchic language and there will be virtually nothing left of it, or perhaps something isolated, without content. An idea will not come from the sentence, but something sad and lonely. (...) Man will dare to express in this language even the most dangerous things" 16 .

The mass media operates with words, and in most cases it is subject to linguistic principles and the purpose of this "world of Flight". The role of the Church is precisely to direct all the steps taken by the word to the "world of Faith". The evangelical message of the Church has the capacity to christen the efforts of the mass media, so that the latter aims to build the man and his spiritual progress. The power that the media has today must be used for the purpose of getting closer to God and to people, of love for all the gifts received from the Almighty God, of cultivating virtues.

\footnotetext{
${ }^{14}$ Jean Baudrillard, „Marshall MacLuhan, Understanding Media: the Extensions of Man”, in L'Homme et la société, no. 5, 1967, p. 229.

${ }^{15}$ Max Picard, Fuga de Dumnezeu, Rom. translation by Patricia Merfu and Pr. George Remete, Ed. Anastasia, București, 1998, p. 21.

${ }^{16}$ Ibidem, pp. 93-94.
} 
The mission of the Church is to bring light where the mass media has contributed to its loss by entire communities or where it is about to extinguish it. The word has within itself the creative force of the One who created it and sowed it from the beginning, therefore it is necessary to re-establish it in the natural order, sowing it on the fertile ground so as to bear fruit and then quench the thirst of man for the Absolute.

In the context of expanding the number of media channels, the Church, being a community that relies on communication, is due to preach the message of God's love for each person, to make all people partakers of the spiritual values they inherited and treasured, to give birth to social networks that do not fall apart from the purpose of creating communions based on love. Of course, it is not at all an easy thing to do away with the vortex created by the speed with which the media has developed today. The Church can encounter countless obstacles in the fight to Christianize the message of the media. " "The problem for the Church does not stem from the fact that it communicates or communicates in parallel with the media. This is basically one of the axes of its mission. It is born and grows from the communication of Jesus Christ to the world through the transmitter of the Father who is the Holy Spirit. The difficulty is that the media and its means constantly produce meaningful revolutions, produce events instead of describing them, change the meaning of space, time, create new social landscapes, encode the whole reality in the spirit of Babel, switching the keys of modern language - from now post-modern - in a code in which the imaginary becomes more real than the real, the artificial more natural than the natural and the indirect information more direct than the most direct of the information (Duilio Corgnali, Le nuove frontiere della comunicazione. Verso una societa dell informazione, in Credere Oggi, (86). no-2 1995, Ed- Messasgero Padova, pp.5-17).' These changes in the communication matrix congest the Christian understanding of the world, falsely converting into excessive emissions the otherwise mediocre messages of a false social-political messiah."17

The Church has the duty to also engage in the media process, and thus to materialize its preaching vocation, giving people the chance of good communication with both their fellows and with God. Media ethics must be a constant concern of the Church and society, so that people are educated in the spirit of good life, of receiving the truth, of the exercise of the good for a common goal.

\section{CONCLUSION}

Nowadays, the mass media is an important opinion-maker, with an overwhelming social receptivity rate, which is why the people employed in the media structures must guide themselves according to moral principles when deciding what they communicate. If they consider that communication that has as essence the truth, objectivity and correctness is necessary, they will be true professionals who are campaigning for people's good.

People need to be protected from the fabrication of news aimed at manipulating and destroying the traditional family, distancing from Christian values, and personal interests. Goodness, love, dignity, truth, integrity must be the fundamental values that spring from the media landscape, and for this to happen, the Church must capitalize on the experience gained over the centuries. The struggle can be considered extremely tough, but we must not forget that God is the Word itself, and we, as bearers of the Word, have the ability to transmit it, to be for all of us "way, truth and life"!

\footnotetext{
${ }^{17}$ Constantin Necula, „Biserica şi mass-media, dinamica unei provocari pastorale” ( The church and the media, the dynamics of a pastoral challenge), see: https://www.crestinortodox.ro/editoriale/biserica-mass-mediadinamica-unei-provocari-pastorale-70105.html, retrieved on 19.09.2019.
} 


\section{BIBLIOGRAPHY:}

[1] Coleman, Steven, „What Is Mass Media? - Definition, Types, Influence \& Examples”, Chapter 11 / Lesson 19, see: https://study.com/academy/lesson/what-is-mass-media-definition-types-influenceexamples.html, retrieved on 18.09.2019.

[2] Bradner, Eric, „Conway: Trump White House offered alternative 'facts' on crowd size”, CNN, January 23, 2017, see https://edition.cnn.com/2017/01/22/politics/kellyanne-conway-alternative-facts/index.html, retrieved on 18.09.2019).

[3] Himma-Kadakas, Marju, ,Alternative facts and fake news entering journalistic content production cycle", in Cosmopolitan Civil Societies Journal, Vol. 9, Nr. 2, 2017, p. 26, see: https://doi.org/10.5130/ccs.v9i2.5469, retrieved on 18.09.2019.

[4] Grigore, Iuliana, Halgaş, Andrada, „«Fabricate» pentru România. Interese ascunse în ştirile false”, 9 January 2019, see: https://intelligence.sri.ro/fabricate-pentru-romania-interese-ascunse-stirile-false/, retrieved on 18.09.2019.

[5] Cătineanu, Tudor, „Cele trei puteri ale statului şi încă una, în plus. Episodul trei: Presa”, published on 13, December, 2015, 12:52, see: https://adevarul.ro/news/politica/cele-trei-puteri-statului-inca-una-plusepisodul-trei-presa-1_566d4ccd7d919ed50e2d6201/index.html, retrieved on 18.09.2019.

[6] Baudrillard, Jean, ,Marshall MacLuhan, Understanding Media: the Extensions of Man”, in L'Homme et la société, no. 5, 1967.

[7] Picard, Max, Fuga de Dumnezeu, (Escape from God), Rom. translation by Patricia Merfu and Pr. George Remete, Ed. Anastasia, București, 1998.

[8] Necula, Constantin, „Biserica si mass-media, dinamica unei provocari pastorale” (The church and the media, the dynamics of a pastoral challenge), see: https://www.crestinortodox.ro/editoriale/biserica-massmedia-dinamica-unei-provocari-pastorale-70105.html, retrieved on 19.09.2019.

[9] Duarte, Dave, „The 7 Mass Media and the 4th Screen”, 19, January 2009, see:

https://www.daveduarte.co.za/blog/2009/1/19/the-7-mass-media-and-the-4th-screen.html, retrieved on 18.09.2019; 